\title{
IMPROVEMENT OF OIL RECOVERY OF THE FLOODED LAYERS AT FORMATION HYDRAULIC FRACTURING
}

• • сифов, • • няк, - • скеров, • • рв рук, • • сифов

T. Yu. Yusifov, S. G. Panyak, A. A. Askerov, Yu. M. Varvaruk, M. Yu. Yusifova

$$
\text { « - } \phi \quad \text { нефть», г } \phi
$$

р льский госуд рственный горный университет, г. $к$ теринбург,

«Global Energy», «ASKON Azticar t»MMC г. $\quad \kappa y$

лючевые слов : гидрор зрыв пл ст ( ); фронт н гнет емыхвод( ); ст тический

фронт н гнет емых вод( ); дин мический фронт н гнет емых вод( ); влияние

н эффективность гидрор зрыв пл ст ; поддерж ние пл стовогод вления () )

Key words: formation hydraulic fracturing (FHF); injected waters front; injected waters static front; dynamic front; influence of the injected waters front on FHF efficiency; reservoir pressure maintenance

ель исследов ния - повышение эффективности геолого-технических мероприятий в предел х р нее нерент бельных з лежей, с учетом х р ктер и объем 3 к чки воды для поддерж ния пл стового д вления.

последнее время число проведенных н месторождениях п дной ибири опер ций $\quad$ зн чительно сниж ется, что обусловлено уменьшением потенци льного фонд скв жин для его проведения. дним из в жных элементов повышения эффективности является совершенствов ние технологии его проектиров ния. оиск оптим льных технологий связ н со зн чительными трудностями, сложными условиями добычи. се мировые нефтег зодобыв ющие комп нии предприним ют р зличные меры по увеличению коэффициент извлечения нефти и г 3 ( $)$. счет применения методов интенсифик ции добычи нефти с использов нием новых технологий и нест нд ртных подходов, можно, к к ок з лось, зн чительно повысить коэффициент извлечения нефти н полуистощенных месторождениях.

месторождениях п дной ибири, н ходящихся н поздней ст дии р зр ботки, обводненность дин мично р стет, в результ те чего сниж ется эффективность геологотехнических мероприятий ( ), которые проводятся н всех эт п х р зр ботки месторождений, но особенно кту льны н поздних ст диях для поддерж ния уровня добычи. идр влический р зрыв пл ст является уник льным видом , применяемость которого пр ктически не огр ничив ется условиями р зр ботки, но его эффективность $з$ висит от пр вильного проектиров ния и применения. ри этом проведение

н обводняющихся 3 леж х должно быть н пр влено н регулиров ние р зр ботки и обеспечение м ксим льной нефтеотд чи пл стов.

н лиз эффективности геолого-технических мероприятий н месторождениях п дной ибири позволил выявить $з$ висимость их эффективности от объем и х р ктеp фронт н гнет емых вод. ст новлено, что при ст тическом фронте н гнет емых вод ( ) эффективность проведения гидр влического р зрыв пл стов зн чительно

\section{4}


выше, чем при дин мическом ( ) обычной пр ктике проведение $\quad$ в зон х счит ется нецелесообр зным из-з риск возможного прорыв трещины в воду 3 к чки. боснов ние для проведения опер ций в зон х дующим: - 3 к чк в проектной ч сти пл стов уже многие годы не ведется; бост точно-извлек емые з п сы присутствуют; в - добыв ющие скв жины н ходятся в бездействии; г - д вление между зон ми отк чки и 3 к чки выровнено.

т тический фронт н гнет емых вод - это неподвижный объем 3 к ч нных р нее вод в пл сте, скв жины при этом н ходятся в бездействии. ри ост новке н гнет ющих воду скв жин подвижн я ее ч сть из з водненных прослоев вытесняется нефтью, поступ ющей из м ловыр бот нных зон, в результ те чего степень 3 воднения и д вление по площ ди з лежи выр внив ются, вод переходит в неподвижное (ст тическое) состояние. ин мический фронт н гнет емых вод - это подвижный объем 3 к чив емых скв жин ми вод, которые сохр няют высокий гр диент д вления.

р ктик применения пок зыв ет, что н ибольший эффект при проектиров нии гидр влического р зрыв пл ст достиг ется тогд , когд выбор скв жин для проведения гидрор зрыв осуществляется с учетом всех ф кторов пл стовой системы, включ я вз имовлияние добыв ющих и н гнет тельных скв жин. некоторых случ ях после проведения опер ции $\quad$ в зон $\mathrm{x} \quad$ н блюд ется к к резкий рост, т к и п дение обводненности продукции, в з висимости от х р ктер первичного з воднения. ледует отметить, что н р звитие р спростр нения трещины, прежде всего, влияют т кие ф кторы, к к регион льный стресс и р спределение пл стового д вления. ри этом, естественно, пл стовое д вление в зоне н гнет ния воды выше, чем в зоне влияния добыв ющих скв жин.

о мере эксплу т ции з лежей условия з лег ния нефти, воды и г 3 в пл сте меняются, процесс сопровожд ется зн чительными изменениями свойств пород, в первую очередь геомех нических х р ктеристик и деформируемости пл ст . ер ми деформируемого состояния породы являются следующие п р метры: -модуль нг , n-коэффициент у ссон , b-модуль объемной упругости, G-модуль сдвиг . ереориент ция основных н пряжений ок зыв ет существенное влияние н упомянутые п р метры и вынужд ет трещину изменить свое н пр вление.

зменения свойств пл ст происходят и н фронте н гнет емых вод, поэтому их следует р ссм трив ть в дин мике - в з висимости от изменения пл стового д вления, темпер туры и других условий в з леж х. ким обр зом, в процессе 3 к чки большого объем воды скв жин ми под воздействием н пор н пряженное состояние породы меняется, созд нн я при трещин р звив ется в сторону высокого н пряжения (рис. 1).
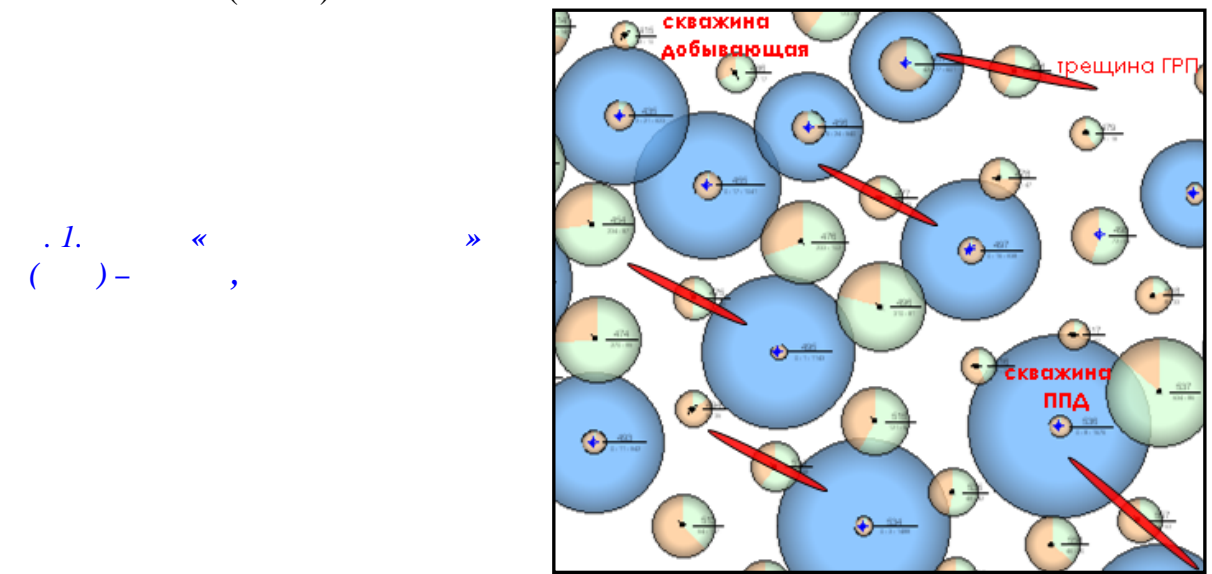

ким обр зом, проведенные н ми полевые р боты убедительно подтвердили выск 3 нные выше теоретические р ссуждения о возможности повышения нефтеотд чи скв жин со ст тическим состоянием 3 к ч нных вод. р ктик подтвердил т кже, что при дин мическом состоянии фронт н гнет емых вод проведение гидр влического p зрыв пл ст менее эффективно и нередко приводит к прорыву воды и обводнению проектных скв жин. оэтому было принято решение подвергнуть гидрор зрыву скв - 
жины, которые н ходились в зон х

, где скв жины

н ходились в бездейст-

вии. езульт ты ок з лись положительными, выведены из консерв ции и успешно 3 пущены в р боту ряд скв жин.

ледует учитыв ть существенное влияние деформ ций пород, формирующихся в процессе эксплу т ции месторождения, н эффективность последующих кое изменение физических свойств определяется пл стовым д влением, гр диент которого может уменьш ться со временем, приходить к ст тическому р вновесию н 3 консервиров нных скв жин х, вновь восст н влив ться при искусственных метод х поддерж ния д вления в 3 лежи. зон х р сположения н гнет тельных скв жин в пл сте д вление повышенное, одн ко, после их ост новки может ст билизиров ться и созд в ть мет ст бильное p вновесие. т ких низкогр диентных условиях 3 к ч нные воды теряют подвижность и созд ют ст тический фронт ( ). то обстоятельство послужило основ нием для принятия решения о проведении опер ций н скв жин х с , что было подтверждено пр ктическими результ т ми (рис. 2).

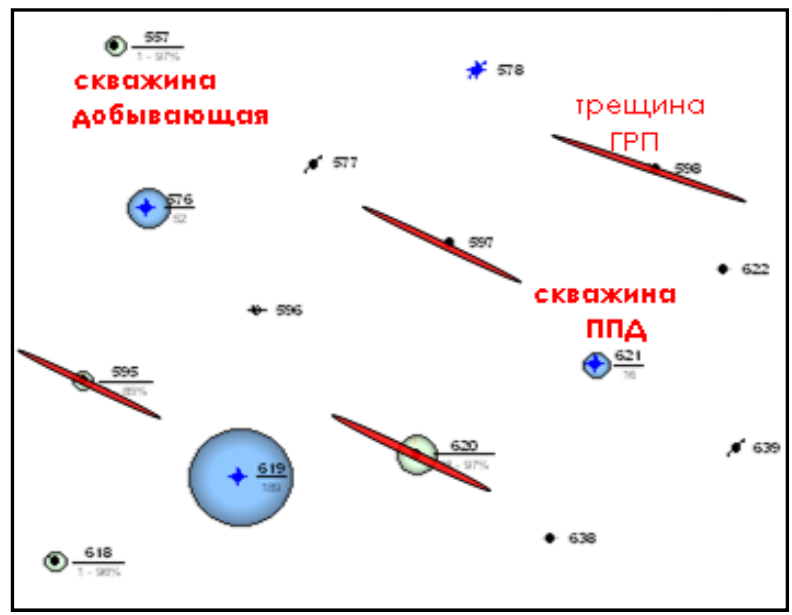

uc. 2 .

, трещин

не прорыв ется

в воду з к ики

пытные р боты пок з ли, что в результ те гидр влического р зрыв искусственно созд нн я трещин соединяет уд ленную, р нее не вовлеченную в р зр ботку обл сть пл ст с зоной влияния добыв ющей скв жины. од с ост точной нефтью вытесняется в сторону трещины, флюид по высокопрониц емым к н л м поступ ет в добыв ющую скв жину, дебит скв жины ст билизируется.

ехническим результ том вышеук з нных теоретических и пр ктических исследов ний является обоснов ние экономической целесообр зности проведения опер ций

в зон х р зр б тыв емых месторождений с фронтом н гнет емых вод, т кже в зон х низкой эффективности з к чки воды. кое обоснов ние 6 зируется н результ $\mathrm{T}$ X предв рительного исследов ния состояния 3 к ч нных вод и фильтр ционноемкостныХ х р ктеристик пл стов. озможность проведения гидр влического р зрыв пл ст в 3 леж х с позволит р сширить спектр опер ций по стимуляции добычи н месторождениях, которые н ходятся н поздней ст дии р зр ботки.

оложительные результ ты внедрения модернизиров нной методики в 3 водненных пл ст х позволяют по-новому пл ниров ть проведение т ких опер ций в сложный, з верш ющий период эксплу т ции з лежей. то к с ется, прежде всего, месторождений п дной ибири, которые нужд ются в применении новых, иногд нетр диционных подходов для повышения эффективности р боты скв жин и м ксим льной нефтеотд чи пл стов. нные методы т кже могут быть использов ны мировыми нефтег зовыми комп ниями в целях интенсифик ции добычи, увеличения коэффициент извлечения нефти.

blводbl

- пытными р бот ми подтвержден выск з нн я р нее теоретическ я возможность эффективного использов ния в зон х фронт н гнет емых вод. ок 3 н возможность дост точно н дежного проведения гидрор зрыв пл ст в зон х ст тичного стояния 3 к ч нных вод. 
- $\quad$ пределены степени рисков прорыв в новообр зов нные трещины

вод 3 к чки при ст тичном (безгр диентном) и дин мичном (высокогр диентном) фронт х н гнет емых вод.

- p ктическ я ре лиз ция полученных выводов позволил провести скв жин х нерент бельных площ дей, увеличить добычу нефти в промышленных м сшт 6 х, повысить коэффициент нефтеотд чи 3 лежей, ре льно увеличить доизвлечение з п сов нефтяных месторождений.

писок литер туры

1. няк . . идрор зрыв пл ст - эффективный метод доизвлечения 3 п сов нефти и г 3 // ефть и г $3 .-$ 2011. - № 5. - . 56-59.

2. ирз дж нз де . ., с нов . ., хтизин . . оделиров ние процессов нефтег зодобычи. - оскв - жевск, 2004

3. сифов . ., тт хов . ., рков . . оэт пный контроль проведения геолого-технических мероприятий н поздней ст дии р зр ботки месторождений // учное обозрение. - 2014. - № 4. - . 38-42.

4. сифов ереориент ция зимут трешины повторного гидрор зрыв пл ст с уменьшением м ссы пропп нт // XIV н учно-пр ктической конференции «еология и р зр ботк месторождений с трудноизвлек емыми 3 п с ми». езисы докл дов. - н п , 23-25 сентября 2014 г. - . 48.

5. сифов идрор зрыв нефтяных пл стов с низким д влением (н примере месторождений « урнефтег з») // ефтег зовое дело. - 2012. - № 3. - . 179-184.

6. сифов . ., из ев . ., олод . ., скеров . . омплексный подход к проектиров нию гидрор 3рыв глинистых пл стов нефтяных месторождений (н примере 14 р совского месторождения

урнефтег з») // ефтег зовое дело. - 2012. - № 2. - . 182-188.

7. сифов . . лияние 3 к чки н выр ботку з п сов при пл ниров нии геолого-технических мероприятий // VIII н учно-пр ктическ я конференция: « тем тическое моделиров ние и компьютерные технологии в процесс p зр ботки месторождений». езисы докл дов. // ефтяное хозяйство. - ф, 2015.

\section{ведения об вторе}

сифов еюб сифоглы, к. т. н., гл вный специ лист "оснефть - фимский н учноисследов тельский и проектный институт», г. $\phi$, тел.89373087202,e-mail:YusifovTY@ufanipi.ru

няк теф н ригорьевич, д. г.-м. н., з ведующий к федрой геологии и , $и$ льский госуд рственный горный университет, г. к теринбург, тел: 8(343)2574105, e-mail: panjaks@rambler.ru

скеров мил киф оглы, спир нт, р льский госуд рственный горный университет, г. $к$ теринбург, тел.8(34936)57539, e-mail: Askerov.A.M@mail.ru рв рук рий их йлович, резидент Global Energy "Abesheron Operating Company», 2. $\kappa y$, еспублик зерб йдж н, тел. 89170480273, e-mail: YVarvaruk@AOC.az

сифов ехп р сиф гызы, инженер, «ASKON Azticar $t » M M C$, г. ку, еспублик зерб йдж н, тел. 89170480273,e-mail:YusifovTY@ufanipi.ru
Information about the author

Yusifov T. Yu., Candidate of Science in Engineering, chief specialist of LLC "Rosneft - Ufa Research and Designing Institute», Ufa, phone: 89373087202, e-mail: YusifovTY@ufanipi.ru

Panyak S. G., Doctor of Geology and Mineralogy, head of the chair of geology, the Ural State Mining University, phone: 8(343)2574105,e-mail: panjaks@rambler.ru

Askerov A. A., postgraduate, the Ural State Mining University, phone: 8(34936)57539, e-mail: Askerov.A.M@mail.ru

Varvaruk Yu. M., president of «Global Energy Abesheron Operating Company», Baku, Republic of Azerbaijan, phone: 89170480273,e-mail: YVarvaruk@AOC.az

Yusifova M. Yu., engineer of «ASKON Azticar $t$ » MMC Baku, Republic of Azerbaijan, phone: 89170480273, e-mail YusifovTY@ufanipi.ru 